\title{
Legal Protection for Online Transportation Service Providers in Transporting Passengers
}

\author{
Desak Nyoman Oxsi Selina* and I Made Wirya Darma \\ Undiknas Pasca Sarjana, Denpasar-Bali \\ *Email: oxsiselina1@gmail.com
}

\begin{tabular}{|l|}
\hline \multicolumn{1}{|l}{} \\
\hline How to cite (in APA style): \\
Selina, D, N, O., Darma, I, M, W. (2021). Legal Protection for Online Transportation Service Providers in Transporting \\
$\quad$ Passengers. Jurnal Hukum Prasada, 8(2), 70-77. doi: https://doi.org/10.22225/jhp.8.2.2021.70-77
\end{tabular}

\begin{abstract}
Transportation is one of the derivative needs in society due to economic, social activities, and so on. In general, there are two transportations, namely based on conventional and online, but the problem is that discrimination often occurs against providers of online-based transportation services, especially in transporting passengers. Thus, the purpose of this study is to find out the legal protection for online transportation service providers in transporting passengers and to find out the legal consequence of discriminating against online transportation service providers in carrying passengers. The method used in this study is normative legal research method. Meanwhile, the legislative and conceptual approach is the approach used in this study. The results of this study showed that the legal protection of online transportation service providers in Indonesia is regulated in legislation including the 1945 Constitution of the Republic of Indonesia which in principle every legal subject must be treated equally before the law, and Law Number 39 Year 1999 which protects that every person is entitled to a job, and legal protection is also contained in Law No. 8 of 1999 which in principle regulates the rights and obligations of business actors. The legal consequence of discrimination is that it can result in criminal and civil law in the form of compensation for imprisonment or fines.
\end{abstract}

Keywords: legal protection; online transportation; passenger

\section{INTRODUCTION}

Transportation is a derived demand caused by economic activities, social activities, and so on. Transportation facilities play a vital role in social and economic aspects, namely through the distribution function of goods, people, and so on from one place to another (Sugiarto et al., 2016). In general, several types of transportation are known, including land, sea and air transportation. With the existence of economic and social developments, means of transportation are currently very much needed by the community, so opening a transportation service business is one of the promising businesses in the world in general and in Indonesia in particular. In general, two transportation service providers include conventional-based (conventional transportation) and application-based transportation (online-based transportation). The development of online-based transportation business in Indonesia is based on the protection of the rights of all Indonesian citizens to express their opinion, as emphasized in Article 28E Paragraph (3) of the 1945 Constitution of the Republic of Indonesia which emphasizes that everyone has the right to freedom of association, assembly, and issue opinions. With this freedom in Indonesia, a phenomenal business idea emerged due to technological advances combined with the thoughts of the nation's children, namely the presence of online-based transportation service providers which are now penetrating rapidly and being utilized by the Indonesian people. Moving on from this, in the concept of a rule of law, both continental Europe and Anglo Saxon, there is 
an element of protection of human rights and the existence of equality before the law, but in terms of transporting passengers online-based transportation service providers, there are no regulations. National regulations often lead to legal problems between conventional transportation and online transportation as well as with other parties.

Several related studies have previously examined legal protection and legal consequences for online transportation service providers. Pujiyono \& Pati (2019) in their study about Legal Protection for the Loss of the Passenger of Online Transportation, showed that there was an legal relationship between service users and online transportation service providers. Consumers have the right to get protection in the form of responsibility for information, legal responsibility for services provided and responsibility for security and comfort. However, for the losses suffered, legal protection for losses incurred by passengers in online transportation mode is still poor due to lack of regulations and the undetermined standard regulations specifically in regulating online transportation modes. Meanwhile, a study conducted by Rachman \& Imron (2020) that examined Legal Protection for Consumers of Online Transportation revealed that there are no regulations governing legal protection for consumers of online transportation service users if the consumers are harmed due to errors, negligence on the part of the driver, or from the business provider of application service providers. Another similar study has also conducted by Pratama (2021) that examined Legal Protection of Passenger on Online Transportation Based on Highway Traffic Act, showed that insurance compensation for passengers who have an accident through PT Jasa Raharja is given to an online application-based transportation company that already has a transportation operation permit based on the provisions of the Ministerial Regulation of Transportation Act Number 108 of 2017 concerning the Implementation of Public Transportation with Public Motorized Vehicles Not On Routes which is carried out based on Act Number 33 of 1964 concerning the Passenger Accident Compulsory Insurance Fund, for online application-based transportation companies that do not have a transportation operation permit, in the event of an accident the passenger does not receive insurance compensation from PT Jasa Raharja. The responsibility of online transportation service providers has complied with Article 188 of Act Number 22 of 2009 concerning Traffic to compensate for the loss of passengers or shippers due to omission in carrying out transportation and road transportation services as well as Article 19 paragraph (1) of Act Number 8 of 1999 concerning Customers Protection regarding the responsibility of businessmen to provide compensation.

Based on the previous studies above, it can be asserted that legal protection for consumers and online transportation service providers some have legal protection but some also do not have legal protection. Therefore, the purpose of this study is to find out the legal protection for online transportation service providers in transporting passengers and to find out the legal consequence of discriminating against online transportation service providers in carrying passengers.

\section{METHOD}

The type of research used in this study is normative legal research because of the absence of norms related to the operational area of the permit to transport passengers on online transportation services. This normative reseach focuses on written regulations (law in book). The statutory approach examines and analyzes all laws and regulations relating to the legal issue being addresed. Meanwhile, the approach used in this study is statutory approach and conceptual approach. The statutory approach chosen because it will use various laws related to the research to be discussed. Besides that, it also uses a conceptual approach, namely using legal concepts from doctrines in legal science (Marzuki, 2005:93). The legal materials in this study were obtained from primary and secondary legal materials. Primary legal materials are legal materials that have binding legal force. Secondary legal materials are materials that provide an explanation of primary legal materials. In addition to primary and secondary legal materials, tertiary legal materials are also used, in the form of materials that provide instructions or explanations for primary and secondary legal materials, such as Indonesian dictionaries and legal dictionaries. To obtain legal material in this study, a literature study was carried out. From the literature 
study, both primary and secondary legal materials will be collected through recording in document form using a file system (Suwitra, 2009). Records using the file system were organized by topic, not by author name. This is done to make it easier to decipher, analyze and make conclusions from existing concepts related to the research to be discussed. Recording in document form using a file system consisting of quotations, summaries and reviews is one of the study materials that can be used as a starting point for thinking to build concepts in this study.

\section{LITERATURE REVIEW}

There are several things that will be discussed in the literature review including:

The definition of services, in the economics of services, is an economic activity that can involve interactions with consumers or consumer goods, but does not cause transfer of ownership. According to Zeithaml and Bitner, they argue that service is an activity in the economic sector with output in addition to products that are consumed and produced at the same time which provide positive and intangible values for buyers. In addition, according to Phillip Kotler, services are any work action offered by one party to another party which in principle does not cause the transfer of any ownership rights (Kurniawan, 2021). From the above definitions, it can be concluded that services are all activities in economic activities that can result in an interaction and involve actions in the form of social contact between the producer and the consumer.

To analyze the problems in this study, several theories related to the problem were used, including the following:

Legal Protection Theory, Etymologically, protection can be defined as a place of refuge, an act of protection. With the recognition as mentioned above means the concept of protection, which obliges the government to prevent and take action against violations of the rights of every legal subject committed by non-state parties by enforcing the applicable law. So in principle, protection is considered to exist if there is a legal structure law enforcement process against rights violations. According to Setiono, he argues that legal protection is an act or effort to protect the community from arbitrary acts committed by the authorities who are not in accordance with legal regulations, which aim to create order and order so as to enable humans (legal subjects) to enjoy their dignity as human (Setiono, 2004). According to Philipus M. Hadjon, legal protection is the protection of dignity, and recognition of human rights possessed by legal subjects based on legal provisions of arbitrariness. According to Phillipus M. Hadjon, there are two forms of legal protection, namely:

Preventive legal protection means that people are given the opportunity to express their opinions before a government decision takes a definitive form aimed at preventing disputes.

Repressive legal protection that aims to resolve disputes (Atmaja \& Budiartha, 2018).

Based on this description, it can be seen that legal protection is all forms of protection made by the government towards human dignity and recognition of human rights in the field of law.

Justice Theory, justice is the most important and foremost goal in the realm of law. So that the formation of the law needs to be guided by justice. According to John Rawls in his book entitled A Theory Of Justice, is as follows:

Justice is the first virtue of social institutions, as truth is of systems of thought. A theory however elegant and economical must be rejected or revised if it is untrue, likewise laws and institutions no matter how efficient and well arranged must be remofed or abolished if they are unjust (Rawls, 1999).

It is in this basic position that an original agreement is made between members of the community on an equal basis. To create justice, the main principles used are:

1) The same freedom as possible, as long as it remains profitable for all parties.

2) The principle of inequality is used for the benefit of the weakest 
DISCUSSION

\section{Legal protection against online transportation service providers in transporting passengers}

According to Soekanto (1999:15), the function of law is to regulate the relationship between the state or society and its citizens, as well as the relationship between fellow citizens, so that life in society runs in an orderly and smooth manner. In essence, law is something abstract, but in its manifestation it can be concrete (Rasjidi \& Putra, 2003). In Indonesia, there is a hierarchy of statutory regulations, including the 1945 Constitution of the Republic of Indonesia, MPR Decree, Regulation, Government Regulations, Presidential Regulations, Regional Regulations. Based on the hierarchy of laws and regulations in fulfilling their rights and obligations as citizens, including online-based transportation providers, some of these laws include the following:

The Constitution of the Republic of Indonesia, in Article (1) paragraph (3) confirms that the Indonesian state is a constitutional state. This means that every action of the state and citizens must be based on and based on the law. In order to achieve this goal in article (28 D) paragraph (1) affirms that everyone has the right to recognition, guarantees of protection, and legal certainty that is just and equal treatment before the law . thus, this affirmation is one form of protection provided to online-based transportation service providers.

Article (16) affirms that everyone has the right to do social work and virtue, to establish organizations for this, including to provide education and teaching, and to raise funds for that purpose in accordance with the provisions of laws and regulations.

Article (120) affirms that every person has the right to protection for his personal development, to obtain education, to educate himself, and to improve the quality of his life so that he becomes a human being who is faithful, devout, responsible, noble, happy, and prosperous in accordance with human rights.

Article (13) affirms that every person has the right to develop and benefit from science and technology, arts and culture in accordance with human dignity for the welfare of his person, nation and humanity"

With this affirmation, it shows that the law regulates legal protection of the personal rights of each person, one of which is the right to a job so that it is an obligation for everyone to respect and uphold the rights of everyone who have been protected by law. .

Law on Consumer Protection, namely Law Number 8 of 1999 concerning Consumer Protection, as affirmed in Article (6) affirms the rights of business actors which explicitly states that:

the right to receive payment in accordance with the agreement regarding the conditions and exchange value of the goods and / or services being traded;

the right to legal protection from consumer actions with bad faith;

the right to defend oneself properly in the settlement of consumer disputes;

the right to rehabilitate a good name if it is legally proven that the consumer's loss was not caused by the goods and / or services being traded;

rights regulated in the provisions of other laws and regulations.

Regulation of the Minister of Transportation of the Republic of Indonesia Number 118 of 2018 concerning the Implementation of Special Leased Transportation, as one of the legal umbrella regarding operational areas, as for the affirmation in Article (7) is:

1. The operating area of Special Charter Transport is determined by considering:

a. determination of the classification of the Urban Area;

b. estimated needs for Special Rental Transportation services;

c. urban or urban development; and

d. availability of adequate road infrastructure.

2. The operating area of Special Charter Transport as referred to in paragraph (1) is 
determined by:

The Minister for the Special Leased Transportation operating area that extends beyond 1 (one) provincial area and that extends beyond 1 (one) provincial area in the Jakarta, Bogor, Depok, Tangerang and Bekasi areas.

With these affirmations it is a form of protection provided by the government to onlinebased transportation service providers in Indonesia.

\section{Legal consequences of discriminating online transportation service providers in carrying passengers.}

According to Syarifin, legal consequences are all consequences that occur from all legal acts committed by legal subjects against legal objects or other consequences caused by certain events by the law concerned that have been determined or considered as legal consequences (Syarifin, 1999). With this explanation, it can be understood that every legal action can lead to legal consequences including acts of discrimination. There are several articles in Law Number 39 Year 1999 that discuss discrimination, including Article (1) point (3) which states that:

"Discrimination is any limitation, harassment, or exclusion that is directly or indirectly based on human differentiation on the basis of religion, ethnicity, race, ethnicity, group, class, social status, economic status, gender, language, political beliefs, which results in a reduction. , deviation or elimination of the recognition, implementation or use of human rights and basic freedoms in life both individually and collectively in the political, economic, legal, social, cultural and other aspects of life ".

With this explanation, this status can be interpreted as saying that nationality is an act against the law. With the act against the law, the rights of the subject of the law being discriminated against are regulated in article (17) that:

"Everyone, without a nation, has the right to obtain justice by submitting applications, complaints and lawsuits, both in criminal, civil and administrative cases as well as being tried through a trial process that is free and impartial, in accordance with the procedural law that guarantees an objective by an honest judge and fair to reach a fair and correct decision".

In connection with discrimination and rights can also have legal consequences. In the criminal law that applies in Indonesia it is known as equality before the law, everyone is equal before the law, whether they have a position in government or common people. So that with this doing so, it is an act against the law for the group that takes care of the rights. In connection with this in the Law of the Republic of Indonesia Number 40 of 2008 concerning the Elimination of Racial and Ethnic Discrimination, there are several articles relating to the law of discriminating in Article (13) which states that everyone has the right to file a claim for compensation through a district court for actions harm that harms him. In addition to the affirmation in Article (14) it is also emphasized that every person who deliberately makes distinctions, eliminates or chooses based on race and which results in the deprivation or respect, the acquisition or implementation of human rights and basic freedoms in an equality in the civil, political, economy and culture as referred to in Article (4) letter (a) shall be punished with imprisonment for a maximum of 1 year and / or a maximum fine of Rp. 100,000,000.00 (one hundred million rupiah).

From the explanation above it can be interpreted that because online-based transportation service providers are one of the legally standing business actors engaged in the transportation sector, when an act of discrimination occurs, it can result in criminal law or civil law consequences for legal subjects who commit discrimination as regulated in the provisions of laws and regulations in force in Indonesia.

In addition to people who discriminate against online-based transportation service providers, legal consequences can also be given to online-based transportation service providers. As emphasized in the Minister of Transportation Regulation Number 118 of 2018 concerning the Implementation of Special Lease Transportation, administrative sanctions can also be imposed on online-based transportation service providers when they commit a violation. Broadly speaking, Article (34) of this Regulation of the Minister of Transportation 
states that violations are classified into three, namely minor violations, moderate violations, and serious violations. Sanctions for such violations are as follows:

Minor offenses, as emphasized in Article (34) Paragraph (2) in general, these violations include the following :

not reporting if there is a change in the management of the company and / or cooperative

not reporting if there is a change in the domicile of the company and / or cooperative

does not report the operational activities of Special Charter Transportation periodically;

reduction or addition of Vehicle identity;

does not maintain the cleanliness and comfort of the vehicle being operated;

not announcing the applicable tariff; and

does not include the amount of the tariff on the application.

The legal consequences of minor violations are emphasized in Article (38) including administrative sanctions in the form of one warning letter and two warning letters.

Moderate violations, as emphasized in Article (34) Paragraph (3) in outline, include the following matters:

1) Violation of the transportation rate

2) Has not paid the obligatory accident coverage and responsibility of the transporter

3) Providing services not in accordance with the established Minimum Service Standards;

4) Not returning a decision letter for operating license and / or Standard Service Electronic Card after a change in the operating license for Special Charter Transportation;

5) Employing vehicle crews who do not meet the requirements in accordance with the provisions of laws and regulations and are not the drivers of the Special Charter Transportation Company concerned

6) Operating the vehicle is not in accordance with the type of service based on the operating license it has

7) Failure to comply with the provisions of working hours and rest periods for drivers

8) Carrying passengers beyond the stipulated capacity; and

9) Failure to pay administrative fines for minor offenses.

The legal consequence of committing violations is being emphasized in Article (39) being subject to administrative sanctions in the form of license suspension letters.

Serious violations, confirmed in Article (34) Paragraph (4) in general, these violations include the following:

Using dual service standard electronic cards;

Operate the vehicle beyond the designated operating area;

Falsifying Vehicle Registration Certificates, service standard electronic cards, vehicle periodic maintenance books from brand holder agents (APM);

Operating a vehicle not equipped with a Vehicle Registration Certificate, service standard electronic card, and a motorized vehicle periodic maintenance book according to the standards of the brand holder agent;

Operate a vehicle whose operating license has expired;

Carried out negligence in the operation of the vehicle resulting in accidents resulting in casualties; and

Not paying administrative fines for moderate violations.

The legal effect when committing a serious violation is emphasized in Article (40), namely in the form of a license revocation sanction. 


\section{CONCLUSION}

Based on the results and discussion explained above, thus it can be concluded that 1) legal protection for online-based transportation service providers in Indonesia is regulated in several laws and regulations including the 1945 Constitution of the Republic of Indonesia, which in principle must be treated equally before the law, and Law Number 39 of the Year 1999 concerning Protection of Human Rights which protects that everyone has the right to a job, and legal protection is also contained in Law Number 8 of 1999 concerning Consumer Protection which in principle regulates the rights and obligations of business actors. 2) The legal consequence of discriminating against online transportation service providers is that it may result in legal consequences in the form of compensation and result in criminal provisions in the form of imprisonment of up to 1 (one) year and / or a maximum fine of IDR 100,000,000 (one hundred million rupiah). Moreover, there are some suggestions to be given to several parties. 1) To the Government, to form laws and regulations with respect to operational area permits to transport passengers and always carry out supervision of online-based transportation service providers. 2) Business actors and the community, that in carrying out their business, they must comply with applicable regulations and respect, respect, and uphold the rights of everyone in accordance with statutory regulations.

\section{REFERENCES}

Andriansyah. (2015). Manajemen Transportasi dalam Kajian dan Teori. Jakarta Pusat: Fakultas IImu Sosial dan IImu Politik Universitas Prof. Dr Moestopo Beragama.

Atmaja, I. D. M., \& Budiartha, I. N. P. (2018). Teori-Teori Hukum. Malang: Setara Press.

Ebta, S. (2012). Kamus Besar Bahasa Indonesia Daring Edisi III.

Kurniawan, A. (2021). Strategi Pemasaran-Pengertian, Fungsi, Konsep, Jenis, Segmentasi, Manfaat, Macam, Para Ahli. Retrieved from gurupendidikan.com website: https:// www.gurupendidikan.co.id/strategi-pemasaran/

Marzuki, P. M. (2005). Penelitian Hukum Edisi Revisi. Jakarta: Kencana Prenada Media Group.

Pratama, D. (2021). Legal Protection of Passenger on Online Transportation Based on Highway Traffic Act. Journal of Law and Legal Reform, 2(4), 569-590. https://doi.org/https:// doi.org/10.15294/jllr.v2i4.49351

Peraturan Pemerintah Republik Indonesia Nomor 24 Tahun 2018 Tentang Pelayanan Perizinan Berusaha Terintegrasi Secara Elektronik

Peraturan Menteri perhubungan Nomor 12 Tahun 2019 Tentang Pelindungan Keselamatan Pengguna Sepeda Motor yang Digunakan Untuk Kepentingan Masyarakat

Peraturan Menteri Perhubungan Republik Indonesia Nomor 118 Tahun 2018 Tentang Penyelenggaraan Angkutan Sewa Khusus Berita Negara Republik Indonesia Tahun 2018 Nomor 1675

Pujiyono, \& Pati, U. K. (2019). Legal Protection for the Loss of the Passenger of Online Transportation. Yustisia Jurnal Hukum, 8(2), 220. https://doi.org/10.20961/yustisia.v8i2.34156

Rachman, A. A., \& Imron, G. Al. (2020). Legal Protection for Consumers of Online Transportation. PalArch's Journal of Archaeology of Egypt / Egyptology, 17(3), 1709-1715. https://doi.org/ https://doi.org/10.48080/jae.v17i3.878

Rasjidi, L., \& Putra, I. B. W. (2003). Hukum Sebagai Suatu Sistem. Bandung: Remaja Rosdakarya.

Rawls, J. (1999). A Theory of Justice. United States of America: Harvard University Press.

Setiono. (2004). Rule of Law (Supremasi Hukum). Surakarta: Magister IImu Hukum Program Pascasarjana Universitas Sebelas Maret.

Soekanto, S. (1999). Penegakan Hukum. Bandung: Binacipta.

Sugiarto, A. J., Hayati, A., Anita, Pribadi, A., Fajar, C., Adestia, D., ... Septaliana. (2016). Transportasi Online VS Transportasi Manual. Jombang.

Suwitra, I. M. (2009). Eksistensi Hak Penguasaan dan Pemilikan atas Tanah Adat di Bali dalam Perspektif Hukum Agraria Nasional. Universitas Brawijaya.

Syarifin. (1999). Istilah-Istilah Dalam IImu Hukum.

Undang-Undang Dasar Negara Republik Indonesia Tahun 1945

Undang-undang Nomor 8 Tahun 1999 Tentang Perlindungan Konsumen Lembaran Negara Republik Indonesia Tahun 1999 Nomor 42 Tambahan Lembaran Negara Republik Indonesia Nomor 3821 
Undang-Undang Nomor 39 Tahun 1999 Tentang Perlindungan Hak Asasi Manusia, Lembaran Negara Republik Indonesia Tahun 1999 Nomor 165, Tambahan Lembaran Negara Nomor 3886

Undang-Undang Republik Indonesia Nomor 40 Tahun 2008 Tentang Diskriminasi Lembaran Negara Republik Indonesia Tahun 2008 Nomor 170 Tambahan Lembaran Negara Republik Indonesia Nomor 4919 